\title{
Politics of Resource Control and Revenue Allocation: Implications for the Sustenance of Democracy in Nigeria
}

\author{
Mukhtar Abdullahi ${ }^{1}$ \\ ${ }^{1}$ Directorate of General Studies, Abubakar Tafawa Balewa University, Bauchi, Nigeria \\ Correspondence: Mukhtar Abdullahi, Directorate of General Studies, Abubakar Tafawa Balewa University, \\ Bauchi, Nigeria. Tel: 234-80-6967-3530. E-mail: muktarabdullahi68@gmail.com
}

Received: August 24, 2014

Accepted: October 14, 2014 Online Published: November 27, 2014

doi:10.5539/jpl.v7n4p176

URL: http://dx.doi.org/10.5539/jpl.v7n4p176

\begin{abstract}
The agitation for the control of resources by the oil producing states in the Niger-Delta area is one of the major challenges confronting the nation and our nascent democracy. This controversial issue has re-surfaced during the recently concluded National Conference held between April and August 2014. The delegates from the oil producing states (south-south) demanded for between $25.5 \%$ to $50 \%$ derivation funding, which was not approve by the conference members. This paper analyses the nature and scope of this agitation and its implications for the sustenance of democratic federal system in Nigeria. The problem of mass poverty and unemployment among youths in Nigeria coupled with collapse of infrastructure, environmental degradation and pauperization of land in the Niger - Delta due to the activities of oil companies were the factors responsible for the trend. The main thrust of the recommendations hinged on ensuring a reasonable and fair sharing formula for the country's resources, and making adequate compensation to the people of the area through infrastructural development by both governments and the participating oil companies.
\end{abstract}

Keywords: resource control, revenue sharing, sustenance of democracy, Nigeria

\section{Introduction}

The quest for a reasonable and fair sharing formula for Nigeria's resources has remained a burning issue since independence. The current debate over resource control in the country centers on the question of whether the Federal Government should continue to have total control of the proceeds obtained in the Niger-Delta area or that the oil producing states should be allowed to take greater percentage of the wealth from their land. The debate has also raised the question about whether government at the federal and states level and the participating oil companies are doing what were expected, in terms, of the provision of goods and services and infrastructural facilities to cater for the needs of the people in the area that suffered from ecological destructions and soil degradation. This appears to be one of the major challenges facing the present civilian dispensation in the country and with which it has to contend for democracy to thrive in the country. The answer to the problem of resource control should be sought partly in the principle of fiscal federalism which provides functional responsibilities and fiscal relations to be performed by the different tiers of government and financial resources that can be raised for provision of collective goods and services (Dunmoye, 2002; Abdullahi, 2013).

\section{Theoretical Consideration}

In order to understand the nature, and dynamics of the agitation for resource control in Nigeria, this paper adopts the theory of pluralism as most appropriate in the explanation of the subject matter. In political theory, pluralism is a concept that describes the heterogeneity of groups that share power in public policy making. According to Dunmoye (2002), the cultural pluralism model was best used by famous scholars like (Nnoli, 2000; Egwu, 2003), to describe the heterogeneous nature of the Nigerian state. From this model we understand that Nigeria is a nation state made up of many ethnic groups (over 300 ethnic groups). This model focuses on the social structure and identifies the socio-cultural forces that influence the political process and determine the political and other relations in the society. This led to increasing fears of domination and marginalization among small groups by the larger, stronger groups. It also created among various groups the desire to gain or exercised control over their own resources which will give them the opportunity to have greater say in the nation's politics (Kwanashie, 2002). This brings into focus the conflict in the relationship between the center and the component units in a federation like Nigeria. More so in the case of Nigeria there had not been any serious attempt at any level 
between these groups to integrate among themselves and evolve into coherent nationhood.

\section{Over View of Revenue Allocation in Nigeria}

Nigeria's revenue allocation policy derives from the character of her federalism. From 1954, all Nigerian constitutions have proclaimed Nigeria as a federation. The constitution provides the basis for fiscal relations, resource control and the principles of management of the economy. Revenue allocation is about the financial relations between and among units of government in the country. It is essentially about the allocation of state resources to the various tiers of government.

As from 1914, when the colonial masters created what was known as Nigeria in an amalgamation exercise which joined together the Northern and Southern protectorates, the search for a suitable revenue sharing arrangement began. This could not be said to have been achieved up to the present time despite several efforts towards that. The recently concluded National Conference which took place in Abuja centre on the twin issues of a suitable arrangement for sharing of resources and sustenance of our nascent democratic experiment.

Years over certain basic principles are used for revenue allocation, out of which four are outstanding: derivation, need, national interest and even development. Others, but with less emphasis, includes, population, geographical peculiarities, absorptive capacity, internal revenue efforts, equality of states, continuity, fiscal efficiency, national minimum standards for national integration, landmass and financial comparability. To ensure that the revenue sharing is done on a rational basis, the exercise has usually been guided by the recommendations of the Commissions/Committees on Revenue allocation.

Historically between 1946 and 1958, four Commissions inquired into Nigeria's fiscal system to make recommendations about revenue allocation amongst the federal and regional governments. The Philipson Commission recommended three principles for sharing revenue among the regions - derivation, even development and continuity of government services. The 1951 Hicks Commission recommended still three principles - derivation, national interest and need. The 1953 Chick's Commission recommended the derivation principle and fiscal autonomy. The 1958 Riesman Commission recommended the sharing of the Distributable Pool Account based on continuity of government services, minimum responsibility of government, need and balanced development.

At independence, the issue of revenue allocation became contentious. In 1964, the Bins Commission recommended increasing the Distributable Pool Account (DPA) from 30 percent to 35 percent. With the advent of military rule the democratic system was terminated and a centralized administration was imposed. This was followed by the restructuring of the federation into 12 states and the Federal government. In 1968, the Dina Committee renamed the DPA, the states Joint Account (SJA) and recommended the basis for its distribution as need, minimum responsibility of states, derivation and balanced development. Under the Military the financial base of the States was weakened and that of the Federal Government strengthened in line with the centralizing tendency of the military.

In 1970 as a result of the increasing wealth from the oil windfall, the Federal Military Government under General Yakubu Gowon promulgated Decree No. 13 which increased financial allocation to the federal government and reduced export duties that went to the States from $100 \%$ to $60 \%$ (Dunmoye, 2002). The argument then was that the Federal government needed an increased financial base to ensure reconstruction and rehabilitation after the civil war. These changes were strengthened in 1971 by the Federal Government's distinction between revenue from on-shore and off-shore production of oil, and its decision to take over all royalties, rent and other revenues from the off-shore oil production. Revenue, which on the principle of derivation had accrued to those states on whose shores oil was produced, now went to the federal government.

More reforms in the revenue allocation were to come under the Aboyede Technical Committee of 1977, and the Okigbo Committee of 1981. But in 1988 the Federal Military Government under General Ibrahim Babangida set up a permanent National Revenue Mobilization, Allocation and Fiscal Commission.

Thus under the Military, the principle of derivation was gradually jettisoned. This led to the various complaints arising from the vertical fiscal imbalance that continued to put pressure on the Federal Government to redress what is considered an unjust situation where states and local governments go begging to the Federal Government for funds to carry out their responsibilities while the Federal Government is accumulating abundant resources which has not led to the advancement of the Nigerian people.

\section{Origin of the Agitation for Resource Control}

The demand by the people in oil producing states (the South-South zone) for resource control is the extreme case of or an indirect clamor for a reversion to the principle of derivation. Experts and political analysts have 
observed that the gross mismanagement of the Nigerian fiscal system (particularly under military rule), justifies this demand which undermines the basis of Nigeria's democracy. The clamor for the control of resources in the Niger Delta area can be traced to the quest for justice and the end of marginalization of the area, for example, the struggle by the people of Ogoni land, under late Ken Saro Wiwa in early 1990s. The protests by the people of Ogoni were crashed by the military junta under late General Sani Aabcha, which led to the execution of Saro Wiwa in 1995.

Talking about their grievances, the people cried of lack of developments even though, the Nigerian oil money is from their area. They also complained about environmental pollution and destruction of their land and rivers by oil companies operating in the area. The effects of oil exploration in the communities and environment in the Niger Delta have been enormous. Local indigenous communities have seen little or no improvement in their standard of living while suffering serious damages to their natural environment. Available records in Nigeria indicated that there were more than 7,000 oil spills between 1970 and 2000 (Amnesty International, 2009). In 1998, the Ijaw people expressed their long-held concerns about loss of control over resources to oil companies, in the Kaiama Declaration which was violently suppressed by the military again, killing at least three protesters and arresting twenty-five others (Amnesty, 2009).

A separate report by the Niger Delta Environmental Survey (NEDES) published in 1997 revealed that:

"Poverty is prevalent in the Niger Delta and has been linked to degradation of agricultural lands and fishing waters. Affected people become impoverished. In many cases, they tend to migrate to become part of the urban poor or to remain in their villages to grapple with the low yielding lands and poor sources of water" (Ogbebulu, 2009).

In fact the region has been devastated by long period of oil exploitation, pollution of waters and almost daily oil spillages and gas flares. These raises temper of the people and created tensions resulting in militancy in the region and form part of what is today known as the agitation for resource control. By 2006, local indigenous activity against commercial oil refineries and pipelines in the region, have increased in frequency and militancy. Employees of the major oil company in the area- the Shell, were the primary targets in hostage taking activities of the local militants. In September 2008, Movement for the emancipation of the Niger Delta (MEND) proclaimed an 'oil war' throughout the Niger Delta against both, pipelines and oil production facilities, and the Nigerian Government. The Government responded by sending more troops and State Security Service into the region, resulting in violence and human rights abuses. In August 2009, the Nigerian Government granted Amnesty to the militants, which saw the militants surrendering their weapons in exchange for a presidential pardon, rehabilitation program, education and skills acquisition. Since then government and private initiatives to develop the Niger Delta region have been increased through the Niger Delta Development Commission (NDDC), and the Development Initiative (DEVIN), a non- governmental organization.

\section{Reasons behind the Clamor for Resource Control}

There are a number of reasons advanced by the advocates of resource control to justify the demands for more revenue by the oil producing states. The major ones are as follows:

- Perceived injustices that characterize the distribution of national resources, particularly the jettisoning of derivation as a major principle of revenue sharing which reduced the amount of funds going to the devastated oil producing areas as of right.

- The general lack of infrastructural development in Nigeria, but particularly in the oil producing areas.

- The attended unemployment and mass poverty among youths in the oil producing areas owing to systematic destruction of the eco-system which led to soil pollution and environmental degradation.

- Failures of the multinational oil companies to contribute to the social and economic development of the oil producing states.

- The activities of ethnic militants made up of unemployed youths in the oil producing communities who were exerting pressure on their political and traditional leaders, thus necessitating political actions.

- The new democratic dispensation which allows for over airing of grievances which were previously suppressed by the military.

It was a combination of these factors which make the demand for resource control a controversial political issue. Viewed from the point of neglect of the oil producing areas coupled with the jettisoning of the principle of derivation in revenue allocation, was enough fact to show the constitutionality of the demand by the people of the Niger-Delta. Derivation which was the leading principle of revenue allocation in the 1960s has by 1980 been 
reduced to $2.5 \%$ of federal revenue, until 1999 when the constitution granted $13 \%$ derivation to oil producing states.

Attempts made by the federal government to address these grievances through setting up of parastatals like the Oil Mineral Producing Areas Development Commission (OMPADEC) and the Niger-Delta Development Commission (NDDC) which replaced OMPADEC have not been adequate enough. The creation of the ministry for Niger-Delta was another effort directed towards addressing the grievances of the people under the civilian dispensation. In addition, the government of late President Umar Musa Yar'adua granted amnesty to the Niger Delta Militants to end years of arm protest by restive youths in the area. The election of President Goodluck Ebele Jonathan from the Niger Delta area in 2011 has greatly reduced the agitations in the South- South and helped to minimize the militant campaigns in the region. But when the government convened a National Conference in April 2014, the issue featured prominently in the deliberations. This suggests that Nigeria need to address the issue once and for all in a constitutional manner.

\section{The Bane of Contention on Resource Control}

Although the controversy over resource control in Nigeria has been on for long, the advent of democracy in 1999 brings up the issue to political discourse championed by the oil producing states. The constitutional provision enshrined in section 162, sub section 2 of the 1999 Constitution came in favor of the oil producing states and sets the stage for a renewed debate. The Constitution under these provisions grants not less than $13 \%$ of the revenue accruing to the Federal Account to the producers of natural resources based on the principle of derivation. However, the oil producing states complain that from 1999 when the first civilian regime took off, until 2009 only $7.9 \%$ and not $13 \%$ was being remitted to them in defiance to constitutional provisions. Former President Olusegun Obasanjo had dismissed the clamor of south-south states for more funding, because according to him the states had nothing to show for the funds they have been collecting from the federal government and as such lacked the moral basis to ask for an increase (Vanguard News Sept, 2002). A political analyst Umar Gana, observed that: "the agitation for resource control has been on since the advent of crude oil as the main stay of the Nigerian economy. But the issue is being over blown and given unnecessary publicity with advent of current democratic dispensation and increased freedom" (New Nigerian, May, 2001). However, Gana agree that the south-south is entitled to compensation based on the fact that the people of the region are paying some price for the discovery of oil. It is disgraceful to see communities that cannot live peacefully because of the flaring of gas, contamination of their fishing and drinking water, he added.

The Chairman, Northern states Governors Forum, and governor of Niger state, Dr Muazu Babangida Aliyu has described as insulting and sad, insinuation by certain members of the National Confab from the south-south that the north was lecherous. Aliyu lamented that some people are busy fermenting trouble in the name of debate for resource control. He observed that for someone to call a section of the country leech is a matter that can cause trouble and that does not need religion or level of education to make it go out of control, emphasizing that, oil is not something that anyone owns and it is sad if some people want to change that law now (Vanguard News August 8, 2014).

Reacting to these allegations people from Niger Delta insisted that what they want is justice, not that they want to have everything to themselves, but rather they are demanding for commensurate compensations for the havoc caused to the environment which put the people in want and penury.

In 2005 the south-south delegates to the then constitutional reform conference staged a walk out when their demands for a $25 \%$ derivation to oil producing states were not approved by the confab. At the recently concluded National Conference the delegates from the south-south demanded that derivation should be increased from the present $13 \%$ to between $25.5 \%$ and $50 \%$. They also agitated that states should control their resources based on the principle of devolution of powers and pay royalties to the Federal Government.

The foregoing shows that the issue of resource control is being politicized by both government and people in the south-south to win sympathy or favor both domestically and outside in order to have more say in the political affairs of the nation.

\section{Conclusion}

The paper has shown that conflicts over resource allocation are largely the outcome of our socio-economic and political short comings, coupled with our own multi ethnic structure inherited from our colonial past. The paper has also shown that agitations for resource control such as we have in recent times in Nigeria could be dangerous to the survival of our nascent democracy. However, Nigerians need to know that resources abound all over the country. There are large deposits of mineral resources waiting to be explored. These resources if fully explored 
and utilized would put to rest the fight over resources and would allayed the fears of deprivation entertained by the antagonist of resource control.

Whatever the circumstances the issue of resource control should not be taken to the extreme. The demand should be based on a call for adequate compensation through re-distribution of the revenue allocation in favor of the devastated areas of the Niger Delta. The agitation by some people in the south-south for a complete control of resources within their territory with consequential payment of royalties to the centre by the federating units is unrealistic. It can only exacerbate the crisis of the Nigerian state. For the agitators to succeed, they must take other parts of the country not endowed with oil, which is the major and dominant revenue earner, into consideration.

To the government there is the need for people oriented policies and programs in all tiers of government. This is the solution to the controversy over resources sharing caused mainly by problem of years of economic and political neglect and mismanagement.

The participating oil companies should play active role in the development of the area through opening more schools and skill acquisition centers.

The government should reconstruct and rehabilitate areas affected by problems of insurgency and internal conflicts.

Above all there is the need to diversify the Nigerian economy to fast track the development of the solid minerals that abound all over the country as indicated above. To this end government should hasten the process of implementation of the recommendations of the national conference, particularly the aspects on resource sharing and national development.

Lastly government should review the revenue allocation formula in the country to reflect the recommendation of the national conference on resource sharing.

\section{References}

Abdullahi, M. (2013). Potential Conflict Areas in Democratic Nigeria, National Conference on Peace and Conflict Management in a Democratic System, Centre for Peace and Conflict Management, University of Jos, 20-23 ${ }^{\text {rd }}$ February, 2013.

Amnesty International. (2009). Nigeria: Petroleum Pollution and Poverty in the Niger Delta. International Secretariat, United Kingdom.

Dunmoye, R. A. (2002). Resource control: Which Way Forward? News Letter of the Social Science Academy of Nigeria, 5(1).

Egwu, S. G. (2004). Contested Identities and the Crisis of Citizenship in Nigeria. Nigerian Journal of Policy and Strategy, 14(1).

Kwanashie, M. (2002). Fiscal Federalism, Resources sharing and Political Economy of Nigeria. News Letter of the Social Science Academy of Nigeria, 5(1).

New Nigerian News Paper, May 22, 2001.

Nnoli, O. (2000). Ethnic Violence in Nigeria. A Historical perspective. In Nnoli O. (Ed.), Communal Conflicts and Displacement in Nigeria. Enugu PANCREP.

Ogbebulu, B. (2009). The Niger Delta Struggle, Federal Government Armnesty and the Way Forward.

Vanguard News Paper, August 8, 2014.

Vanguard News Paper, September 11, 2002.

Weekly Trust News Paper, December 2006.

\section{Copyrights}

Copyright for this article is retained by the author(s), with first publication rights granted to the journal.

This is an open-access article distributed under the terms and conditions of the Creative Commons Attribution license (http://creativecommons.org/licenses/by/3.0/). 